\title{
Translation vs Localization: What's the Difference?
}

\author{
Vadim V. Sdobnikov* \\ Linguistics University of Nizhny Novgorod \\ 31a Minin Str., Nizhny Novgorod, 603155, Russia
}

Received 01.06.2018, received in revised form 01.09.2018, accepted 12.09.2018

The principal goal of the article is to substantiate the idea that a wider application of some forms of translators' activities does not necessarily entail development of new concepts and approaches to translation. To achieve this goal, the following tasks have been solved: the main approaches to translation specified in European Translation Studies and their provisions have been considered, new trends in translation including the wider use of information technologies and expansion of the areas in which new forms of translation/interpreting are used have been analyzed, definitions of localization as translators' activity together with substantiation of the distinction between localization and translation have been considered. Moreover, the article provides analysis of definitions of transcreation, transadaptation and transculturation viewed by some scholars as special strategies aimed at bridging the gap between cultures and adapting a text to recipients belonging to another culture.

The methodology of investigating translation/interpreting should be based on the combination of the traditional equivalence-oriented approach and the communicative-functional approach to translation. The statements presented in the article are based on the communicativefunctional approach which implies placing the "translation event" into the context of a certain communicative situation.

The article proves that the so called localization and transcreation presented by many scholars as specific forms of translators' activity do not deserve this status, and must be viewed as types of translation proper. "Cultural adaptation" of a text performed in the process of "localization" and "transcreation" is another term for pragmatic adaptation widely used by translators and translation scholars for a long time. What matters in such situations is the degree of pragmatic/cultural adaptation.

Keywords: communicative-functional approach, information technologies, localization, internationalization, transcreation.

Research area: philology.

Citation: Sdobnikov, V.V. (2018). Translation vs localization: what's the difference? J. Sib. Fed. Univ. Humanit. soc. sci., 11(9), 1487-1498. DOI: 10.17516/1997-1370-0317.

(C) Siberian Federal University. All rights reserved

* Corresponding author E-mail address: artist232@rambler.ru

This work is licensed under a Creative Commons Attribution-NonCommercial 4.0 International License (CC BY-NC 4.0). 


\section{Introduction}

It is quite obvious that it is only practical translation that enriches Translation Studies with new ideas and concepts. Initially, Translation Science has emerged due to the need to realize the essence of translation/interpreting as a practical activity, to realize the essence of the tasks being solved by a translator and their solutions, to comprehend the main approaches to translation and interpreting. However, relations between Translation Studies and the practice of translation seem to be more complicated; they can be characterized as relations of interdependence: Translation Studies, being the result of thorough analysis of the peculiarities and conditions of translating activity, impacts this activity, offers certain guides for finding optimal solutions in the constantly changing conditions of performing translating activity. That is why the major tasks of Translation Studies include the development of general principles of training translators and interpreters who would be able to meet the requirement of the translation market. Those are the principles which determine the quality of the final product of any academic activity, of a professional translator, and - ultimately - the general quality of translation activities.

The conditions for performing translation activities have significantly changed during the recent decades. Now translators work in the computerized, digital world entangled in the Web; they use various information technologies including TM systems, machine translation and the like. Moreover, greater importance was gained by the types of translation/interpreting that previously had been on the periphery of the translator's profession or had been even non-existent (audiovisual translation, community interpreting, transediting, transcreation, audiodescription, etc.). Frequently, these types of translation activity are seen as essentially or entirely different from the so called translation proper and even are opposed to the latter. Ives Gambier argues that the word 'translation' "... is often replaced by or competes with other terms which can in turn vary widely according to the particular sector of activity in which they are used... They reflect diversified professional realities and practices as well as distinct paths of research" (Gambier, 2016: 56). It is absolutely true that as new translators' activities have been brought to the forefront of the profession or, at least, to the visual field, researchers and translators are impelled to analyze and comprehend the theoretical foundations of these activities. The attempts result in new terms, or labels, as well as in new conclusions that, seemingly, are bound to enrich Translation Studies with new ideas and concepts.

But I am concerned by the fact that these ideas, being undoubtedly new, do not help us understand the essence of translation precisely; on the contrary, they make 
the term 'translation' more obscure and diffused. Moreover, some statements reveal a vulgarized vision of translation, an over-simplified approach to its definition, referring to the initial stage in Translation Studies development, instead of guiding us along a new, much brighter way of the development of Translation Science.

The goal of the article is to analyze new approaches to defining translation and its place in the digital world, and to reveal false conceptions that risk to degrade translation results in the future.

\section{The main approaches to research in translation}

Ives Gambier notes that two paradigms have been developed in Translation Studies. On the one hand, "the more conventional conceptualization of translation that has endured for centuries through the paradigm of equivalence has evolved into one more oriented toward the public or audience - that is, the paradigm of the cultural turn" (Gambier, 2016: 888). It is noteworthy that the essence of this paradigm is its orientation toward the public or audience. The fact is an inspiring one. Suffice it to recall the statement made by Vilen Komissarov, one of the founders of the linguistic Translation Studies in Russia and the author of the equivalence levels theory: "A translator must realize precisely for whom and for what purpose (s)he is translating a text, what task the target text will perform, who will use the target text and in what way" (Komissarov, 2001: 357). I can only regret that this statement has remained unnoticed by adherers of the Linguistic Translation Studies or has been blatantly ignored by them. To prove the idea, I can cite the article of Olga Petrova and Victor Lanchikov: “... to use any text (both ST and TT) for different purposes, it is not necessary to change it each time, to adapt it to the needs of each recipient" (Petrova, Lanchikov, 2017: 44). The statement illustrates an obvious contradiction between the recipient-oriented approach to translation and the one that completely ignores the needs and expectations of the recipient. The declarations similar to the one cited above are made within the paradigm that is traditionally called linguistic, or text-oriented, as I call it. It means that the linguistic approach to translation is full of contradictions, its guideposts are not precise, although its more pronounced orientation toward the recipient cannot be denied either.

The second translation paradigm, in Ives Gambier's perception, is the "one that reflects the platforms and mediums through which the activity of translation is now carried out. In this sense, the paradigm of the book transforms into one of the digital and Web (where the text to translate becomes multimodal). This rapidly changing context 
can explain the proliferation of terms used to designate what was once translation" (Gambier, 2016: 888). There is no doubt that the conditions in which a translator works - in terms of purely technological matters - have changed dramatically. But can it be a good reason to state that a new theoretical paradigm has emerged in Translation Studies? Anthony Pym who is more cautious in establishing new translation paradigms seems to share Gambier's opinion: he claims that new IT are not just additional tools but systems that "... are altering the very nature of the translator's cognitive activity, social relations, and professional standing" (Pym, 2011).

I disagree with both I. Gambier and A. Pym. I believe that opposing the equivalence paradigm (linguistic approach) to the paradigm based on the use of new media is artificial and illogic. While the first paradigm really reveals a certain attitude to and perception of translation as an activity, as well as a certain vision of the nature of translation and the essence of the tasks solved by a translator, the second "paradigm" takes into account only a set of tools used by a translator to accelerate the translation process and to enhance its effectiveness. After all, a translator can use the same approach to translation using translation memory systems or not using them. It had been the fact even before new IT appeared. On the contrary, different translators can use different approaches using the same tools. In the $16^{\text {th }}$ century Martin Luther and his opponents defended quite different approaches to the translation of the Scripture, and all of them used goose-quills to write on paper or parchment. In the $19^{\text {th }}$ century all translators used the same tools but what striking difference there was between approaches toward translation (paradigms) used by Russian translators Irinarch Vvedensky and Afanasy Fet! What has changed ever since? If we talk about the correlation between the approaches to translation and the means used to do it - practically nothing.

It is the functionalist approach that can be opposed to the equivalence paradigm (it is precisely what Erich Prunč writes about in his book devoted to the history of European and American Translation Studies (Prunč, 2015: 57)). To designate this approach different terms can be used: functionalist approach in Europe and USA, communicative-functional approach - in Russia. The communicative-functional approach implies that translating is the activity which ensures the possibility of the activity (production, commercial, cognitive, recreational activity) of translation users ("consumers" of translation) and/or initiators (commissioners) of translation. According to this approach, translating as an activity is embedded into the structure of a communicative situation (situation of communication). A translator is expected to take into account specific features of the situation, the goal of translation, the needs 
and expectations of the communication actors, the purely linguistic factors which make an impact on the translation process and its result including differences between the languages, the text type and the purpose of the ST. For more detailed description of the communicative-functional approach refer to (Sdobnikov, 2016; 2017).

It is noteworthy that there is no hard and fast line between the purely linguistic approach (equivalence paradigm) and the communicative-functional approach. I view the latter as a general translation ideology, a sort of translator's thinking that is used to create an environment in which all kinds of translators' activities are made effective.

\section{Translation vs localization?}

Recently, localization has become an important service in the translation market. Many translation companies try to attract new clients using the statement that they offer not only translation proper but localization as well. Localization is presented as an activity that is entirely different from "translation proper" though it can be a part of a translator's sphere of responsibility (see, for example, the Website of Linguacontact translation company, Saint-Petersburg (Lokalizatsiya perevoda, Lingvakontakt)). Yet, translation proper is defined as reproduction of the content of the ST and sometimes of its formal features in the TT while localization is defined as adaptation of the meanings of words and phrases to the perception of the TT recipients (Lokalizatsiya perevoda, Lingvakontakt). The idea that translation and localization are different activities is so wide-spread now that it has been even reflected in the title of the draft standard of the translator's profession: initially it was planned to call it "Translator" but the draft developers have voted to name it "Specialist in Translation/Interpreting and Localization".

Let us have a look at the differences between translation and localization in the perception of managers of translation companies and some translation scholars.

I shall start with how some managers and translators view and define localization. According to the information on the Internet, the translation process includes several stages. When it comes to translation of websites, computer games, mobile applications and the like, an internationalized text in the SL is produced at the initial stage. Internationalization (sometimes the term "globalization" is used instead) implies adaptation of the text to the international market. "The goal is to annihilate all cultural peculiarities to produce a text that could be easily adapted to any language environment or a country. If regional peculiarities cannot be annihilated at the initial stage, it must be done at the localization stage" (translation mine. - V.S.) (Yazykovaya lokalizatsiya...). 
The internationalization results in a "product that is localized in many languages and is based on the universal, internationalized variant without any reference to the ST; necessary changes are made in the text to adapt it to the tastes of the target audience and to the cultural and social situation in the specific location" (translation mine. V.S.) (Internatsionalizatsiya i lokalizatsiya...). Localization is viewed as the cultural adaptation of the text. Another website reveals the fact that "localization implies adaptation of a source text to the cultural context of the country into the language of which the translation is made. In other words, it can be said that localization is a type of adaptation" (translation mine. - V.S.) (Lokalizatsiya perevoda, Fridge). These definitions are interesting for the fact that adaptation is covertly detached from translation and is presented as a specific activity performed in addition to translation. The same idea is voiced on still another website: "Localization is often confused with translation, but these terms actually mean two different things... Translation is the process of converting text from one language to another. Translation is one aspect of localization, but localization is more extensive.” (What Is Localization..., 2018). It seems that localization is a kind of polishing, finishing of the resulting text, "adaptation" of the text to the target culture. Accordingly, localization acquires a special status of its own: "Localization is often seen as translation of the highest level" (translation mine. V.S.) (Yazykovaya lokalizatsiya...).

Examples and statements on other websites are also intended to convince us of the same idea. In particular, managers of Fridge translation company (Ukraine) state the following: "Verkhovnaya Rada is a purely Ukrainian reality, and it is very difficult to translate it into English; the literal translations Supreme Council or Supreme Board are not quite coherent for English-speaking people. That is why transliteration is used in the English version of the website - Verchovna Rada, with the word 'parliament' in brackets because a parliament is a legislative body in English-speaking countries (translation mine. - V.S.)" (Lokalizatsiya perevoda, Fridge). I am not going to comment on the use of transliteration to render the Ukrainian realia. But the use of the word 'parliament' in brackets to make this incoherent (in perception of English-speaking people) notion is well-justified, and is applicable to many situations. Moreover, as a means of solving the general translation problem of rendering realia, it is listed among methods of pragmatic adaptation which had been considered as an indispensable component of the translating procedure long before the appearance of new information technologies. Suffice it to see the corresponding chapter in Vilen Komissarov's manual (Komissarov, 1990: 211-215). 
Surprising is the following statement: "A good translator should render figures such as temperatures, weights, lengths, currencies, dates in accordance with the local standards" (translation mine. - V.S.) (Lokalizatsiya perevoda, Fridge). Does it mean that a translator not engaged in the localization process has the right to leave such figures in their initial form without thinking of whether the TT recipient would understand them correctly? I believe that we can come across such facts only in the activity of "bad translators". But the authors of the cited articles think it to be a norm for translation and a special task of localization, which is not true. So, what is so special about localization if a well-trained and responsible translator always solves this task in the process of translation proper. Maxim Oryel argues: "Just try not to change the sequence of the date and month written in numbers in translating from American English into Russian, and 11/12 will elusively turn into December 11 . Haven't we been told about it in the university? Certainly, we have" (translation mine. - V.S.) (Oryel, 2011: 92-93).

It seems that either many players in the translation market have not heard about such fundamental truths or their professional thinking has not been formed yet. In any way, it explains their admiration for localization presented as a means to ensure the required impact on the TT recipient who lives in another country. But can it be otherwise in "translation proper"? It cannot. That is why the following statement is truly pathetic: "It is obvious that localization is a very complicated activity that requires, besides a good command of language, knowledge of the cultural peculiarities, customs and traditions, political systems of other countries" (translation mine. - V.S.) (Lokalizatsiya perevoda, Fridge). This statement implies that a translator who is not engaged in localization does not need to know all these nuances of the other culture.

It is obvious that in the modern translation market many players devoid of the profound knowledge of the Translation Theory share a naïve and vulgarized vision of translation as a reproduction of the ST content by means of rendering meanings of words. "...For whatsoever is more than these cometh of evil". At least, when localization is not required.

In reality, pragmatic, cultural adaptation is an integral part of any professional translation (with exception for highly specialized texts) because translation is always made across cultures. Ignoring this fact is fraud with serious consequences for a translator and his/her audience.

In this situation it is consoling that the naïve vision of these "two activities" (translation vs localization) shared by translators-practitioners is not theoretically grounded. And indeed, it is hardly possible. There are no sober-minded scholars who 
would dare to make translation insipid depriving it of its culture-bound component. But I could not help but dwelled upon this alarming and disturbing trend in the translation business. Its mere existence affects translators' minds and deprives them of the possibility to comprehend the true essence of translation.

\section{Cultural turn in translation?}

Let us briefly touch upon another phenomenon related not to the practice of translation but to Translation Studies. I mean the so called transcreational approach to translation. Evgeniya Malyonova argues that "according to the transcreational approach, translation is a tool used to reproduce ideas and images of the source text in the context of the target culture" (Malyonova, 2018: 54). She believes that the transcreational approach to translation is a manifestation of the so called "transcreational turn" in Translation Studies. She states that such creative practices as transcreation, transadaptation and transculturation can be used in translation to bridge the gap between cultures in one way or another.

These notions are defined by Evgeniya Malyonova as follows: "Transcreation is a strategy of creative re-thinking a ST segment and of the subsequent creation of a text in the target language with due account of the multimodal and culture-bound context, the character of the communicative situation, technical and legal limitations, the recipient's anticipated reaction... Using transadaptation, a translator changes various elements of cultural, visual, audio and other codes in order to better integrate the text into the matrix of the target culture. The greatest integration of the ST into the target culture is achieved by the use of the strategy of transculturation which implies a complete alteration of the text and production of a new product of creative activity that is not perceived as a strange object by representatives of another culture" (translation mine. - V.S.) (Malyonova, 2018: 54).

The definitions above indicate to the fact that the "strategies" differ in the "depth", or degree, of what is traditionally called pragmatic, or cultural, adaptation. I can hardly agree that it is only transcreation that requires to take into account the character of the communicative situation and the anticipated reaction of the recipient. I believe that it is an indispensible part of any translation regardless of the "strategies" used. And translation scholars have long agreed on this. The term "transadaptation" may be applied to such specific types of translation as audiovisual translation and localization, i.e. translation of websites, computer games, mobile apps, etc. Instead of the term "transculturation" the term "re-writing" is used in the traditional Translation Studies (though without any stress on cultural differences or distance). Vilen Komissarov 
defines re-writing as a translator's activity aimed at "producing a parallel text in the target language that is not intended to be a translation of the original and does not function as a translation but starts from the original that has served as an impetus, a reason or a guide for producing the text in another language (Komissarov, 1997: 69). I can conclude that the transcreational approach is an attempt to describe what has already been described in Translation Studies but in other terms. So, don't we posit plurality without necessity?

The question arises because attempts have been made to present some forms of translation as so culturally bound that they cease to be forms of translation and are alleged to become some special activities distinct from the translation proper. One of the distinctions of such "pluralities" is the degree to which the text is transformed due to the distance between cultures as well as to the special needs of the TT recipient and the mode of the TT utilization. I am confident that these factors are essential in all communicative situations and always must be taken into account by a translator. The "cultural turn" that emerged in Translation Studies in 1980s resulted in understanding of the need to adapt a text to the target culture but it did not require new "pluralities" or new terms that would be used to designate them. There was no need for that.

In this case we deal with the same phenomenon as in the case of localization but of the more complicated nature. Adherers of localization as a special activity, to their surprise, have suddenly found out that differences between cultures must be taken into account when a text is produced in a target language; adherers of the transcreational approach pay major attention to the situations in which the factor of culture is of special significance but they forget that this factor is built permanently into the structure of the translator's activity and is indispensable of the translation process. Whatsoever is more than these cometh of evil.

\section{Conclusion}

Some new trends in Translation Studies and professional translators' activity have been analyzed in the article. I have not dwelled on some areas conditioned by expansion of audiovisual translation and community interpreting. Their theoretical interpretation deserves thorough consideration.

I can conclude that some scholars and practitioners share a naïve vision of translation as a mere reproduction of cognitive information mainly in the form in which it is presented in the ST. Cultural adaptation aimed at bridging the gap between cultures is presented by them as a special activity distinct from translation. In the 
situations when the factor of culture is of special significance or ways of using the TT are peculiar, translation scholars tend to view a translator's activity as somewhat special or assign a status of a special "strategy" to this activity. I think that in all cases we should treat such activities as translation proper carried out with different degrees of cultural adaptation in different communicative situations. Accordingly, translation results, i.e. target texts, differ in their degree of transformation. Therefore, localization, transcreation, transadaptation and transculturation are forms of translation made with different degrees of pragmatic, cultural adaptation. And there is no need to label wellknown notions with new terms.

A question arises: does the notion of translation become blurry and indistinct? It does not. In accordance with the communicative-functional approach, translation is a verbal and cognitive activity of a translator aimed at producing a TT that reproduces the content and formal features of the ST to the degree required in the given communicative situation and that helps recipients and/or commissioners of the translation effect their substantive work. When we say that translation is varied, we just state the fact. Acknowledging this fact, translation scholars should also recognize that a translator is expected to meet expectations of the translation consumers. To do it, (s)he is obliged to adapt a text to another culture - both in translation and localization.

\section{References}

Gambier, I. (2016). "Perevod i perevodovedenie na perekrestke tsifrovykh tekhnologii" [Translation and Translation Studies at the Crossroads of Digital Communications]. In Vestnik SPbSU. Philology. Asian Studies. Journalism, 4, 56-74.

Gambier, I. (2016). "Rapid and Radical Changes in Translation and Translation Studies". In International Journal of Communication, 10, 887-906.

Internatsionalizatsiyailokalizatsiyavperevode[Internationalizationandlocalization in translation]. In translation bureau "Express" ["Express" translation agency] Internationalization. Available at: http://termin74.ru/articles/internationalization/

Komissarov, V.N. (2001). Sovremennoe perevodovedenie [Modern Translation Studies]. Moscow, ETS.

Komissarov, V.N. (1990). Teoriya perevoda (lingvisticheskie aspekty) [Translation Theory (Linguistic Aspects)]. Moscow, Vysshaya Shkola.

Komissarov, V.N. "Novye tendentsii v perevodovedenii" [New Trends in Translation Studies]. In Information and Communication Aspects of Translation, Nizhny Novgorod, LUNN. 
Lokalizatsiya perevoda [Translation localization]. In Fridge. Available at: http:// fridge.com.ua/2011/02/lokalizatsiya-perevoda/

Lokalizatsiya perevoda [Translation localization]. In Byuro perevodov "Lingvakontakt" [Linguacontact translation company]. Available at: https:// linguacontact.com/localization/

Malyonova, E.D. (2018). Kreativnye praktiki v perevode [Creative Practices in Translation]. In Translation and Culture: Interaction and Interdependence, Vologda, Nizhny Novgorod.

Oryel, M.A. (2011). "Nanofilologiya, ili byvayut li melochi v perevode?" [Nanophilology, or Are There Any Trifles in Translation]. In Problems of Translation Theory, Practice and Didactics, 14, Nizhny Novgorod.

Petrova, O.V., Lanchikov V.K. (2017). Skolko gitik umeet perevod. O, odnoi strategii perevodcheskikh strategii [How many GTs can translation manage. On one concept of translation strategies]. In Bridges. Journal of Translators, 1, Moscow, R.Valent, 40-50.

Prunč, E. (2015). Ways of Development of Western Translation Studies. From Language Asymmetry to the Political One. Moscow, R. Valent.

Pym, A. (2011). "What Technology Does to Translating". In Translation and Interpreting. Vol. 3. 1(2011). Available at: http://trans-int.org/index.php/transint/article/ viewFile/121/81

Sdobnikov, V.V. (2016). "In defence of communicative-functional approach to translation”. In Procedia. Social and Behavioral Studies, 231, 92-98.

Sdobnikov, V.V. (2017). "Communicative-Functional Approach in Russian Translation Studies: Where Does It Come From?”. In Science Journal of VolSU, Linguistics, (3), 71-79.

What Is Localization, And When Do You Need It? (2018). In Languageline. Available at: http://blog.languageline.com/what-is-localization

Yazykovaya lokalizatsiya [Language localization]. In Vikipediya. Svobodnaya entsiklopediya [Wikipedia. Free encyclopedia]. Available at: https://ru.wikipedia.org/ wiki/Языковая_локализация 


\section{Перевод и локализация: в чем различие?}

\section{В.В. Сдобников}

Нижегородский государственный лингвистический университет им. Н.А. Добролюбова

Россия, 603155, Нижний Новгород, ул. Минина, 31 а

Основная цельь настоящей статьи - доказать, что расширение сферы использования некоторых видов переводческой деятельности не обязательно приводит к появлению новых подходов и концепџий в переводоведении. Для достижения поставленной иели были решены следующие задачи: рассмотрены основные подходы к осуществлению переводческой деятельности, выделяемые в зарубежном (европейском) переводоведении, и способы их обоснования, проанализированы новые тенденции в переводческой деятельности, включая широкое использование новых информациионых технологий и расширение сферы использования определенных видов перевода, проанализированы определения локализачии как вида переводческой деятельности и предлагаемые практиками обоснования разграничения локализации и перевода. Кроме того, рассмотрены определения транскреации, трансадаптации и транскультурации, представляемые в переводоведческой литературе в качестве особых стратегий осуществления перевода, определяемых необходимостью адаптировать переводимый текст к восприятию получателей, принадлежащих к иной культуре.

В настоящее время наиболее оптимальной методологией изучения перевода является сочетание традиционной парадигмь эквивалентности и коммуникативно-функиионального подхода к переводу. В качестве основного подхода рассматривается коммуникативно-функииональный подход, предполагающий помещчение «переводческого события» в структуру определенной коммуникативной ситуации.

В статье обосновывается мнение, согласно которому локализация и транскреация, выделяемые в настоящее время в качестве отдельных видов перевода, вовсе таковыми не являются, а представляют собой разновидности собственно перевода. Культурная адаптаџия текста, осуществляемая в процессе «локализаџии» и «транскреации», на самом деле есть прагматическая адаптация, хорошо известная практикам и теоретикам перевода. Значимой в этих ситуациях является лишь степень, или глубина, прагматической/культурной адаптации.

Ключевые слова: коммуникативно-функциональный подход, информационно-коммуникационные технологии, локализация, интернационализация, транскреация.

Научная специиальность: 10.00.00 - филологические науки. 